\title{
Insider dan Outsider dalam Penafsiran: Upaya Membaca Tafsir dalam Dua Sisi Perspektif Kim Knott
}

\author{
Mahbub Ghozali ${ }^{1}$ \\ ${ }^{1}$ Program Studi Ilmu Al-Qur'an dan Tafsir, UIN Sunan Kalijaga Yogyakarta \\ e-mail: mahbub.ghozali@uin-suka.ac.id
}

\begin{abstract}
ABSTRAK. Penelitian ini bertujuan untuk untuk menemukan metode dan pemaknaan baru dalam kajian tafsir. Penemuan metode dimaksudkan untuk memberikan pandangan baru berkaitan dengan objektivitas penafsiran yang seringkali diperselisihkan oleh banyak kalangan. Untuk mencapai tujuan tersebut, penelitian ini menggunakan metode kualitatif dengan teknik penelitian studi pustaka. Untuk memperdalam analisa data, penelitian ini menggunakan pendekatan insider dan outsider yang dikenalkan oleh Kim Knott. Penelitian ini menemukan bahwa sintesis antara penafsiran sarjana Barat dengan sarjana Islam menghasilkan satu pemahaman yang bersifat tekstualis-historis secara bersamaan. Dalam artian bahwa al-Qur'an dipahami tidak hanya pada penekanan hukum dan sakralitasnya, akan tetapi aspek historisnya yang melibatkan sturktur budaya dan sejarah yang melingkupi al-Qur'an diturunkan. Kecenderungan sarjana Barat dalam memahami al-Qur'an dalam aspek kritisnya, dapat menekan subjektivitas penafsiran Islam yang cenderung tendensius. Dalam konteks ini, penelitian ini menyimpulkan bahwa perspektif insider dan outsider tidak hanya digunakan dalam kajian studi Islam yang luas, akan tetapi dalam diaplikasikan pada studi Islam yang spesifik. Oleh sebab itu, penggunaan perspektif ini dapat diaplikasikan pada bidang ke-Islaman spesifik lainnya, agar pemahaman terhadap Islam dapat lebih objektif.
\end{abstract}

Kata kunci: Outsider, Insider, Tafsir, Kim Knott, Orientalisme

\begin{abstract}
This study aims to find new methods and meanings in the interpretation's field. The finding of the method is intended to provide new insights regarding the objectivity of interpretation which is often disputed by many scholars. Based on this, this study uses qualitative methods with library research techniques. To in depth the data analysis, this study uses the insider and outsider approaches introduced by Kim Knott. This research finds that the synthesis between the interpretation of Western scholars and Islamic scholars produces a textual-historical understanding simultaneously. In the sense that the Quran is understood not only in the emphasis of the law and its sacredness, but also on its historical aspects which involve the cultural and historical structures that surround the Quran. The tendency of Western scholars to understanding the Quran in its critical aspect can suppress the subjectivity of Islam scholars interpretation which tends to be tendentious. In this context, this research concludes that the insider and outsider perspectives are not only used in Islamic studies, but also in specific aspect of Islamic studies. Therefore, the use of this perspective can be applied to other specific fields of Islam, so that an understanding of Islam can be more objective.
\end{abstract}

Keyword: Outsider, Insider, Tafsir, Kim Knott, Orientalism 


\section{PENDAHULUAN}

Melakukan pembacaan tafsir dengan menggunakan perspektif Barat, terkadang disangsikan oleh banyak kalangan. Hal demikian disebabkan oleh ketentuan syarat bagi seorang penafsir yang harus memiliki kaidah yang lurus. ${ }^{1} \mathrm{Hal}$ ini bermakna bahwa syarat pertama bagi seorang mufassir adalah Islam, sehingga orang Barat yang tidak beragama Islam tidak boleh diambil penafsirannya. Hal demikian, dalam pandangan M. Quraish Shihab merupakan syarat yang ketinggalan zaman, sehingga dibutuhkan pembaharuan. ${ }^{2}$ Menurut Shihab, hal yang dibutuhkan dalam penafsiran bukan berkaitan dengan persoalan keyakinan, akan tetapi berkaitan dengan sikap objektif dalam memandang ayat. Shihab menguatkan argumentasinya melalui penafsiran terhadap Q.S. al-Taubah (9): 6. Dalam konteks pemahaman ayat ini, kalangan musyrik berpotensi untuk memahami ayat secara objektif, selama ia tidak menampakkan permusuhan dengan Islam. ${ }^{3}$ Dalam konteks ini, penafsiran yang dilakukan oleh sarjana Barat terhadap Islam dapat diterima, kecuali mereka teridentifikasi memiliki niat untuk melawan Islam. Terdapat banyak tokoh Barat yang dikenal melakukan penelitian terhadap Islam dan al-Qur'an secara objektif. Bahkan, hasil karya mereka banyak digunakan oleh ilmuwan Islam dalam melakukan pengembangan pengetahuan. ${ }^{4}$

Sedangkan penafsiran yang dilakukan oleh mufassir klasik memiliki kecenderungan terhadap perdebatan madhhabiyah. ${ }^{5}$ Perdebatan semacam ini dilakukan secara turun temurun dari masa ke masa. Akibatnya, produktivitas dalam kajian tafsir yang objektif tidak pernah ditemukan. ${ }^{6}$ Realitas semacam ini kemudian memunculkan gerakan-gerakan baru dalam kajian tafsir kontemporer yang lebih bersifat ilmiah. ${ }^{7}$ Meskipun demikian, upaya kritis yang dilakukan oleh sarjana Islam kontemporer dalam memahami al-Qur'an tidak menghilangkan pengalaman ke-Islaman mereka, sehingga pengalaman subjektif mengenai Islam rentan masuk dalam wilayah penafsiran yang menjadikan mereka terjebak pada prasangka-prasangka teologis yang bersifat subjektif. ${ }^{8}$ Hal inilah yang menjadikan penafsiran mereka tidak dapat disebutkan sebagai bentuk tafsir yang objektif. Upaya untuk menghadirkan tafsir yang objektif dapat dilakukan dengan menghadirkan dua bentuk tafsir, yakni tafsir sarjana Barat dan Islam. Dengan kata lain, menghadirkan outsider dan insider dalam penafsiran.

Kajian memahami tafsir dari dua arah dibutuhkan karena masih belum terdapat upaya untuk memberikan gambaran pemahaman terhadap realitas penafsiran dalam pandangan 323.

${ }^{1}$ Mannâ' Khalîl Al-Qațțân, Mabâhith Fî Ulûm Al-Qur'an (Riyâd': Manshûrât al-'AŞr al-Hadîth, 1973), hal.

${ }^{2}$ M.Quraish Shihab, Kaidab Tafsir Syarat, Ketentuan, Dan Aturan Yang Patut Anda Ketahui Dalam Memahami Ayat-Ayat Al-Qur'an (Tangerang: Lentera Hati, 2013), hal. 397.

${ }^{3}$ Shihab, hal. 398.

${ }^{4}$ Zakariya Hâkim Zakariya, Al-Mushtashriqûn Wa Al-Islâm (Kairo: Dâr al-Kutb al-'Arabiyah, 1965), hal. 168; Fazlur Rahman, “Some Recent Books on the Qur'ān by Western Authors," The Journal of Religion 64, no. 1 (January 22, 1984): hal. 73, https://doi.org/10.1086/487077.

${ }^{5}$ Mohammed Arkoun, "Towards a Radical Thinking of Islamic Thought," in Modern Muslim Intellectual and The Quran, ed. Suha Taji-Faruki (Oxford: Oxford University Press, 2004), hal. 139.

${ }^{6}$ Hasan Hanafi, "Method of Thematic Interpretation of The Quran," in The Quran as Text, ed. Stefan Wild (Leiden: E.J. Brill, 1996), 210.

${ }^{7}$ Abdul Mustaqim, Epistimologi Tafsir Kontemporer (Yogyakarta: LKiS, 2011), hal. 52.

${ }^{8}$ Kim Knott, "Insider/Outsider Perspective," in The Routledge Companion to The Study of Religion, ed. John R. Hinnells (New York: Routledge, 2005), hal. 243. 
outsider dan insider. Pemahaman dalam dua konsep ini selalu diarahkan pada ruang yang besar, yakni Islam. Hal semacam ini dapat ditemukan dalam penelitian Bayu Fermadi dengan judul Insider-Outsider dalam Studi Islam. ${ }^{9}$ Fermadi memberikan penjelasan mengenai pemikiran Amir Hussain, Amina Wadud, Omid Safi dan Sa'diyya Shaikh. Dalam kesimpulannya, aspek insider dapat ditemukan dalam pemikiran Amir Hussain dan Sa'diyya Shaikh yang mendasarkan bentuk pemikirannya kepada narasi-narasi Islam yang ditemukan di al-Qur'an dan Hadis terhadap konsep hukum. Sedangkan, pengalaman kehidupan barat yang dialami Amina Wadud dan Omid Safi memberikan pandangan berbeda dengan mempertimbangkan pandangan barat terhadap Islam.

Penelitian yang lebih spesifik berkaitan dengan outsider dan insider dalam kajian Islam adalah upaya yang dilakukan oleh Suarni dengan judul Pendidikan Islam Menjawab Tantangan. ${ }^{10}$ Penelitian ini menggunakan perspektif outsider dan insider dalam pengembangan pendidikan pesantren. Perspektif tersebut, dalam kesimpulan Suarni dapat mengembangkan pendidikan pesantren, sehingga dapat menghadapi perkembangan pengetahuan di era globalisasi. Pesantren harus meningkatkan kurikulum yang berbasis teknologi, agar pendidikan di pesantren bersifat visioner dan antisipatoris. Sedangkan secara mayoritas, penelitian yang menggunakan perspektif outsider dan insider berkaitan dengan pembahasan metodis mengenai pemikiran Kim Knott dalam studi agama. ${ }^{11}$

Penelitian yang ada menjelaskan mengenai kebutuhan studi agama yang lebih objektif dengan melakukan pemahaman sekaligus dalam konsep pengetahuan outsider dan insider. Penelitian yang spesifik dalam menggunakan pandangan ini menemukan arah baru dalam memahami pendidikan yang lebih dapat menyesuaikan dengan perkembangan zaman. Sedangkan konsep penting dalam studi Islam yang terletak pada pemahaman atas al-Qur'an tidak banyak dibahas. Kemungkinan untuk memahami al-Qur'an secara objektif dengan mengacu pada pandangan insider dan outsider, dibutuhkan untuk mengembangkan keilmuan tafsir yang nantinya akan dapat membantu dalam memberikan dasar bagi bangunan keilmuan lainnya. Dengan kata lain, penemuan makna dalam ayat-ayat al-Qur'an yang objektif dapat menggunakan cara memadukan pandangan ousider dan insider secara bersamaan.

Penelitian ini bertujuan untuk menemukan metode dan pemaknaan baru dalam kajian tafsir. Penemuan metode dimaksudkan untuk memberikan pandangan baru berkaitan dengan objektivitas penafsiran yang seringkali diperselisihkan oleh banyak kalangan. ${ }^{12}$ Dengan menggunakan pendekatan ini, perdebatan objektivitas dapat diminimalisir dengan membawa dua pemahaman, yakni pemahaman insider dan outsider dalam memahami ayat. Sedangkan pemaknaan baru dapat ditemukan dengan melakukan persilangan pemahaman antara

\footnotetext{
${ }^{9}$ Bayu Fermadi, “Insider-Outsider Dalam Studi Islam," Jurnal Ilmiah Spiritualis: Jurnal Pemikiran Islam Dan Tasawuf, vol. 4, 2018, http://ejurnal.iaipd-nganjuk.ac.id/index.php/spiritualis/article/view/49.

10 Suarni Suarni, "Pendidikan Islam Menjawab Tantangan Suarni," Tarbawy : Jurnal Pendidikan Islam, vol. 6, December 1, 2019, https://jurnal.lp2msasbabel.ac.id/index.php/tar/article/view/1237.

11 Musnur Hery, "Pengembangan Studi Islam Perspektif Insider-Outsider," Intizar 22, no. 2 (December 24, 2016): 199, https://doi.org/10.19109/intizar.v22i2.941; Ahmadi, "Perspektif Insider/Outsider Dalam Studi Agama (Mengurai Gagasan Kim Knott)," Jurnal Al-Himayah 2, no. 2 (October 1, 2018): 191-204, http://journal.iaingorontalo.ac.id/index.php/ah; Untung Khoiruddin, "Insider/Outsider Perspective in Religions and Islamic Studies," Jurnal Pemikiran Keislaman 24, no. 2 (September 23, 2015), https://doi.org/10.33367/tribakti.v24i2.175.

${ }^{12}$ Nasr Hamid Abu Zayd, Al-Qur'an, Hermeneutika, Dan Kekuasaan, trans. Dede Iswadi, A. Rohman, and Ali Mursyid (Bandung: Reseach for Quranic Studies, 2003), hal. 42-46.
} 
penafsiran sarjana Barat dengan Islam agar dapat ditemukan sintesa yang tidak terpengaruh oleh aliran-aliran tertentu.

Penelitian ini berangkat dari argumen bahwa penafsiran yang selalu dikaitkan dengan tendensi religius dari diri sang penafsir, dapat diminimalisir tanpa harus melakukan rekonstruksi metodis yang berujung pada truth claim masing-masing penafsir. Penafsiran atas suatu ayat al-Qur'an dimungkinkan untuk mencapai titik tengah yang bernilai objektif dengan merelasikan antara penafsiran yang diberikan oleh sarjana Islam dengan sarjana Barat. Hasil penafsiran ini jauh lebih objektif dibandingkan hanya meninjau penafsiran hanya dari satu sisi, yakni Barat (outsider) ataupun Islam (insider). Dengan demikian, upaya melakukan tafsir dengan dua sisi, outsider dan insider dapat menjadi alternatif baru dalam metode tafsir.

\section{METODE PENELITIAN}

Penelitian ini menggunakan metode kualitatif dengan teknik penelitian studi pustaka (library research). Penggunaan metode kualitatif mempertimbangkan metode ini dalam melakukan penilaian dan analisa secara mendalam terhadap fenomena ataupun suatu isu. ${ }^{13}$ Sedangkan dalam segi sumber data, penelitian ini menggunakan dua sumber data, yakni sumber data primer dan sumber data sekunder. Sumber data primer yang digunakan dalam penelitian ini adalah tafsir-tafsir klasik maupun modern yang dikarang oleh sarjana Muslim dan produk tafsir yang dihasilkan oleh sarjana Barat yang tidak menampakkan permusuhan terhadap Islam (revisionis).

Teknik analisa data dalam penelitian ini menggunakan empat langkah. Pertama, melakukan reduksi data. Reduksi data digunakan untuk menganalisa secara mendalam perbedaan yang terdapat dalam penafsiran yang dilakukan insider dan outsider. Kedua, melakukan display data. Diplay data dilakukan untuk melakukan narasi atas data-data yang relevan. Ketiga, melakukan interpretasi data. Keempat, melakukan penarikan kesimpulan. ${ }^{14}$ Selain itu, untuk memperdalam proses analisa data, penelitian ini menggunakan pendekatan insider dan outsider yang dikenalkan oleh Kim Knott. Pendekatan ini digunakan karena dapat melihat data dari dua sisi penafsiran, sehingga dapat memungkinkan untuk melakukan pemahaman atas data secara objektif.

\section{HASIL}

\section{Al-Qur'an dalam Pandangan Islam dan Barat}

Setiap umat Islam meyakini bahwa al-Qur'an adalah pedoman yang bersumber dari Allah melalui Nabi Muhammad. Hal demikian disepakati oleh seluruh umat Islam, baik bagi sarjana klasik maupun modern. Hal yang diperselisihkan adalah proses pemahaman atasnya. Pertentangan pemahaman atas al-Qur'an dalam tradisi Islam dimulai sejak masa Tabi'in. ${ }^{15}$ Perdebatan dalam wilayah pemahaman atas al-Qur'an semakin meruncing pada masa keilmuan

${ }^{13}$ Michael Quinn Patton, How to Use Qualitative Methods in Evaluation (New York: SAGE Publications, 1987), hal. 9.

${ }_{14}$ Matthew B. Miles and A. Michael Huberman, Qualitative Data Analysis (a Source Book of New Methods) (Beverly Hills: SAGE Publications, 1984), hal. 16.

${ }^{15}$ Husayn Alawî Mahr, Al-Madhkhal Ila Târikh Tafsîr Wa Al-Mufassirîn (Iran: Markaz Musțafâ al-'Alamî, 1392), hal. 151. 
Islam masuk pada era yang lebih mapan. Tafsir dibawa pada orientasi madhahbiyah dan teologis, sehingga memunculkan perdebatan mengenai keabsaahan penafsiran didasarkan pada orientasi aliran yang diyakini oleh para penafsir. ${ }^{16}$

Pada masa selanjutnya, yakni abad ketujuh, kedelapan, dan kesembilan, studi mengenai al-Qur'an mengalami kemajuan pesat. Terdapat hampir 300 kitab tafsir yang lahir selama masa ini, yang dapat diklasifikasikan menjadi empat ketegori; tafsir yang berpegangan pada ijtihad (tafsîr bi al-ra'y), tafsir yang berpegangan pada riwayat (tafsir bi al-riwayah), tafsir yang membahas mengenai hukum dalam al-Qur'an (tafsîr al-âhkâm), dan tafsir irfâni. Kesuksesan keilmuan dalam bidang tafsir pada masa ini dilanjutkan pada masa berikutnya yakni abad kesepuluh, kesebelas dan keduabelas, melengkapkan kajian tafsir sebelumnya. Bagi kalangan sejarahwan, masa ini merupakan masa keemasan dalam sejarah peta pemikiran Islam (al-aşr al-żahabiy). Tidak hanya kemapanan dalam bidang tafsir yang muncul pada abad ini, begitu juga kemapanan dalam bidang ilmu-ilmu al-Qur'an sehingga pada masa berikutnya, kajian tafsir maupun ilmu-ilmu al-Qur'an merupakan pengulangan dari kajian-kajian sebelumnya.

Efek dari kemapanan ini menurut Arkoun memiliki dua konsekuensi. Pertama, semua pendekatan dan metode analisis dibatasi sehingga tidak bisa melampaui pagar dogmatik. Kedua, tafsir yang dianggap memiliki otoritas adalah korpus tafsir ortodok. ${ }^{17}$ Akibatnya proses penafsiran al-Qur'an diperketat dengan sejumlah kualifikasi dan akhirnya menjadi sangat terbatas. Munculnya sektarianisme dalam produk-produk tafsir menjadikan kegiatan penafsiran tidak lagi dilandasi oleh tujuan menjadikan al-Qur'an sebagai hidayah bagi manusia, melainkan sekedar sebagai alat legitimasi bagi disiplin ilmu tertentu atau mendukung kekuasan dan madhhab tertentu, sehingga validitas tafsir hanya didasarkan pada kecenderungan penguasa. ${ }^{18}$

Sikap-sikap sektarianisme inilah yang mendorong lahirnya kritik dari para pemikir dan mufassir masa selanjutnya. Mereka berupaya mendekonstruksi dan merekonstruksi model penafsiran yang dinilai telah jauh menyimpang dari tujuan al-Qur'an. Tradisi penafsiran pada abad pertengahan (abad ke-7-13 H.) dianggap telah terkontaminasi oleh fanatisme madzhab dan kepentingan politik tertentu sehingga tampak sangat ideologis, subjektif dan tendensius (talwiniyah mughridah). Atas dasar hal ini, pada masa selanjutnya, Ahmad Khan dan Muhammad Abduh mencoba melakukan reinterpretasi terhadap al-Qur'an dengan menggunakan analisis kritis terhadap korpus tafsir konservatif. Mereka cenderung melepaskan diri dalam perdebatan madhhab dan memanfaatkan kajian-kajian keilmuan modern. Mereka kemuadian merekonstruksi model pengkajian terhadap al-Qur'an dengan epistemologi baru yang dapat menampung segala perubahan zaman dan kemajuan ilmu pengetahuan. ${ }^{19}$ Abduh memandang bahwa kitab-kitab tafsir pada masa sebelumnya tidak lebih dari sekedar pemaparan atas berbagai pendapat para Ulama yang saling berbeda dan pada akhirnya menjauhkan dari tujuan diturunkannya al-Qur'an sebagai kitab petunjuk. ${ }^{20}$

Hal yang sama dilakukan oleh Naşr Hâmid Abû Zayd yang memandang bahwa solusi yang ditawarkan oleh kalangan konservatif, pada esensinya mengingkari tujuan dan maksud

16 Mahr, hal. 202.

${ }_{17}$ Mohammed Arkoun, "Contemporary Critical Practices and The Quran," in Encyclopedia of The Quran, ed. Jane Dammen McAuliffe, vol. 1 (Leiden: Brill, 2001), hal. 426.

${ }^{18}$ Hanafi, "Method of Thematic Interpretation of The Quran," hal. 210.

${ }^{19}$ Mustaqim, Epistimologi Tafsir Kontemporer, hal. 52.

${ }^{20}$ Muĥmmad Abduh, Tafsîr Al-Qur'an Al-Karim Juz' Amma (Kairo: Mața'ah MiŞr, 1341), hal. 16. 
syariah, ketika solusi tersebut memisahkan teks dari realitas. Naşr Hâmid menganggap bahwa kristalisasi konsep teks bisa jadi dapat menghilangkan sebagian aspek dari kekacauan tersebut dan dapat menyingkapkan topeng wajah reaktif yang sebenarnya dari pemikiran tersebut dan pengaruhnya dari warisan budaya serta menyingkapkan kenyataan tidak adanya pemisahan dari arus peradaban kelas hegemonik. ${ }^{21}$ Meskipun demikian, pola rekonstruksi tafsir yang dilakukan pada masa ini tidak secara total membuang warisan peninggalan tafsir-tafsir pada abad sebelumnya. Hasan Hanafi menganggap bahwa persoalan yang terjadi bukanlah pembaharuan warisan budaya atau warisan budaya dan pembaharuan, sebab permulaannya adalah warisan budaya bukan pembaharuan. Pembaharuan hanyalah dalam rangka kesinambungan dalam kebudayaan nasional, landasan masa kini, dorongan ke arah kemajuan, dan ikut terlibat dalam persoalan perubahan sosial. Pembaharuan bagi Hanafi adalah penafsiran kembali terhadap warisan budaya sesuai dengan kebutuhan masa. Yang lama mendahului yang baru, dan otentisitas merupakan dasar bagi kekinian. ${ }^{22}$

Warisan tradisi masa lalu ini juga dapat mengantarkan kita pada konteks masa pemwahyuan, dimana dengan pengetahuan terhadap masa al-Qur'an turun dapat mempermudah untuk memahami maksud dari ayat-ayat tersebut. Karena setiap ayat yang turun, dengan penggunaan istilah-istilahnya berhubungan erat dengan situasi yang melingkupinya. Menurut Fazlur Rahman, kajian terhadap pandangan-pandangan mufassir, terutama dari generasi awal akan sangat membantu untuk memahami al-Qur'an secara holistik. Konsepsi ini oleh Rahman disebut sebagai gerakan ganda (double movement) tahap pertama. Untuk selanjutnya, pandangan umum yang diperoleh dari penggalian dan sitematisasi prinsipprinsip umum kemudian dispesifikkan dan direalisasikan pada kondisi sekarang. ${ }^{23}$

Sedangkan dalam pemikiran Barat, al-Qur'an murni dijadikan objek penelitian tanpa adanya keyakinan teologis tentang fungsi dan posisi al-Qur'an dalam keagamaan mereka. Meskipun demikian, terdapat dua golongan pengkaji Barat yang fokus dalam melakukan penelitian terhadap al-Qur'an, yakni revisionis dan tradisionalis. Revisionis adalah sarjana Barat yang melakukan penelitian terhadap al-Qur'an dengan motif awal meragukan dan mempertanyakan klaim kebenaran Islam atas al-Qur'an. Sedangkan kalangan tradisionalis, meyakini klaim kebenaran Islam tanpa meragukannya. ${ }^{24}$ Salah satu tokoh revisionis yang melakukan kajian terhadap al-Qur'an adalah John Wansbrough. Wansbrough menganggap bahwa al-Qur'an merupakan kitab yang baru muncul setelah 150 tahun pasca wafatnya Nabi Muhammad. ${ }^{25}$ Pernyataan ini bertujuan untuk menghilangkan otentisitas al-Qur'an sebagai kitab suci umat Islam. Sedangkan salah satu tokoh dari kalangan tradisionalis adalah Wilfred Cantwell Smith yang menyebutkan bahwa pernyataan kebenaran satu agama didasarkan pada pernyataan kebenaran yang disampaikan oleh penganut agama tersebut. Pandangan semacam

${ }^{21}$ Nasr Hamid Abu Zayd, Tekstualitas Al-Qur'an: Kritik Terbadap Ulumul Qur'an, trans. Khoiron Nahdliyyin (Yogyakarta: LKiS, 2013), hal. 10-11.

22 Hasan Hanafi, Al-Turâth Wa Al-Tajdîd: Mawqifuna Min Al-Turâth Al-Qadìm (Beirut: Muassasah alJamîiyah, 1992), hal. 13.

${ }^{23}$ Fazlur Rahman, Islam Dan Modernitas Tentang Tranformasi Intelektual, trans. Ahsin Mohammad (Bandung: Penerbit Pustaka, 1985), hal. 8.

24 Andrew Rippin, "Foreword," in Quranic Studies: Sources and Methods of Scriptural Interpretation, trans. Andrew Rippin (New York: Prometheus Books, 2004), hal. xii.

25 Andrew Rippin, “Analisis Sastra Terhadap Al-Qur'an, Tafsir Dan Sirah: Metodologi John Wansbrough," in Pendekatan Kajian Islam Dalam Studi Agama, ed. Richard Martin, trans. Zakiyuddin Baidhawy (Surakarta: Muhammadiyah University Press, 2001), hal. 201-222. 
ini dalam istilah Charles J. Adams disebut sebagai pendekatan irenic, yakni pendekatan yang mendasarkan pada kebenaran penganut agama. ${ }^{26}$

Perspektif lain dijelaskan oleh Fazlur Rahman terkait tipologi kajian Barat terhadap alQur'an. Rahman membaginya menjadi tiga kecenderungan; Pertama, kajian yang berupaya untuk menemukan pengaruh agama-agama sebelumnya terhadap Islam. Kedua, kajian yang berupaya menemukan sisi historis dalam al-Qur'an dengan menjelaskannya secara kronologis. Ketiga, kajian yang menjelaskan secara tematik atau penjelasan secara keseluruhan dalam alQur'an. $^{27}$

\section{Penafsiran al-Qur'an Sarjanawan Barat dan Islam: Sebuah Upaya Diakronik}

Penafsiran Q.S. al-Mujâdalah (58): 1-2

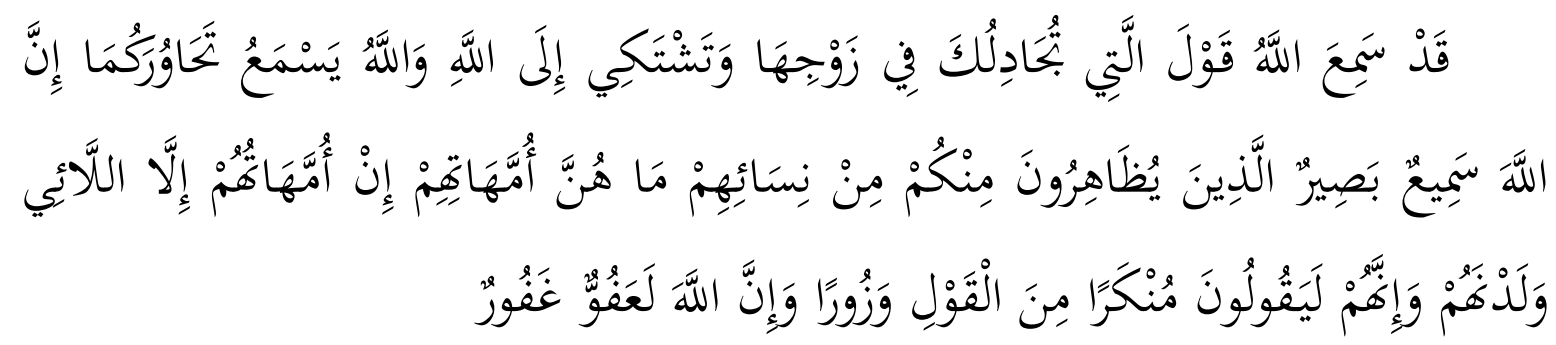

Sesungguhnya Allah telah mendengar perkataan wanita yang mengajukan gugatan kepada kamu tentang suaminya, dan mengadukan (halnya) kepada Allah. Dan Allah mendengar soal jawab antara kamu berdua. Sesungguhnya Allah Maha Mendengar lagi Maha Melihat. Orang-orang yang menzhihar isterinya di antara kamu, (menganggap isterinya sebagai ibunya, padahal) tiadalah isteri mereka itu ibu mereka. Ibu-ibu mereka tidak lain hanyalah wanita yang melahirkan mereka. Dan sesungguhnya mereka sungguh-sungguh mengucapkan suatu perkataan mungkar dan dusta. Dan sesungguhnya Allah Maha Pemaaf lagi Maha Pengampun.

Dalam konteks ayat ini, para ahli tafsir Islam memandang bahwa ayat ini berkaitan dengan Hawlah binti Tha'labah yang telah di żihar oleh suaminya Aus bin al-Şâmit. Ia mengadukan perkara tersebut kepada Rasulullah. ${ }^{28}$ Hawlah menyebutkan bahwa suaminya menikah dengan dirinya ketika ia masih muda. Akan tetapi, ketika usianya telah lanjut, suaminya hendak mentalaknya. Mendengar pengaduan tersebut, Rasulullah merespon bahwa ia tidak pernah menerima penyelesaian atas kasus yang menimpa Hawlah, ${ }^{29}$ kemudian ayat ini diturunkan. Dalam tradisi Arab, ìihar merupakan salah satu ucapan yang bermakna talak, sehingga Hawlah menjadi gelisah disebabkan suaminya tidak bermaksud untuk metalaknya dan merasa kasihan terhadap anaknya. Dalam riwayat lain yang disebutkan Ibn Kathîr, Kawlah merasa kasihan bila meninggalkan suaminya karena ia sudah tua dan badannya lemah. ${ }^{30}$ Oleh sebab itu, ia menemui Rasul untuk memberikan penyelesaian terhadap perkara tersebut.

${ }^{26}$ Charles J. Adams, "Islamic Religious Tradistion," in The Study of the Middle East: Research and Scholarship in the Humanities and the Social Sciences, ed. Leonard Binder (New York: Wiley, 1976), hal. 38.

${ }^{27}$ Fazlur Rahman, Tema-Tema Pokok Al-Qur'an, trans. Anas Mahyuddin (Bandung: Pustaka, 1980), hal. x-

xi.

${ }^{28}$ Muhammad bin Jarîr Al-T,abarî, Jâmi’ Al-Bayân Fî Ta'mîl Al-Qur'an, vol. 23 (Beirut: Muassasah al-Risâlah, 2000), hal. 220.

${ }^{29}$ Ismâil bin Umar bin Kathîr, Tafsîr Al-Qur'an Al-'Ai்îm, vol. 8 (Riyâd': Dâr al-Țayyibah, 1999), hal. 34.

${ }^{30}$ Kathîr, 34. 
Dalam pandangan sarjana Barat, ayat ini juga disebutkan berkaitan dengan Hawlah binti Tha'labah. Bagi Ingrid Mattson motif yang melatar belakangi keinginan Hawlah untuk tetap bersama dengan suaminya adalah berkaitan dengan tradisi Arab yang dikenal sebagai bangsa yang masih menonjolkan hukum kesukuan. Kehormatan dicapai oleh seorang perempuan masa itu adalah berkaitan dengan kecantikan yang dimiliki, semangat, murah hati dan loyalitas. Ketika pesona kecantikan memudar, seorang wanita bisa berharap untuk mendapatkan rasa hormat dan syukur yang meningkat atas hubungan yang telah dia bangun selama bertahun-tahun. Maka untuk tetap menjaga kehormatan dan kemulyaan yang didapatkan, Hawlah mengadu kepada Tuhan. ${ }^{31}$

Ketika Hawlah berharap penyelesaian terhadap problemnya kepada Rasul, ia sempat merasa kecewa. Nabi Muhammad mengindikasikan keberlakuan kebiasaan orang Arab dalam melakukan zi ihar, karena tidak ada ayat yang turun yang mengubah hukum tersebut. Akan tetapi, Khawla tidak menyerah dan merasa bahwa kebiasaan ini tidak adil. Ia terus mengeluh kepada Tuhan, hingga ayat tersebut diturunkan. ${ }^{32}$

Penafsiran Q.S. al-Fîl (105)

Dalam pandangan sarjana Islam, secara mayoritas mereka menyebutkan babwa surat ini berkaitan dengan penyerangan tentara bergajah yang dipimpin Abrahab ke Makkah. ${ }^{33}$ Ibn Kathîr memberikan pendapat bahwa kisah tersebut sebagai permulaan yang baik bagi kelabiran Nabi Muhammad. ${ }^{34}$ Berdasarkan pendapat kalangan mufassir, alasan Abrahah melakukan penyerangan ke Makkah adalah didorong oleh niatan untuk memindabkan haji yang dilakukan oleh orang Arab masa itu dari Makkah ke Yaman. Untuk mencapai niat tersebut, ia ingin menghancurkan Ka'bah. ${ }^{35}$ Alasan yang hampir sama juga disebutkan oleh Fakhr al-Dîn al-Râzî yang menyebutkan niat Abrahah karena dipengaruhi oleh sikap kedengkiannya kepada masyarakat Makkah yang telah dianugrahi kemulyaan dengan adanya Ka'bah. ${ }^{36}$

Sedangkan dalam pandangan sarjana Barat, faktor pendorong yang menjadi alasan adanya penyerangan ke Makkah dipengaruhi oleh stabilitas politik semenanjung Arab pada akhir abad ke-6 M. Pada masa itu, suku Quraysh yang menguasai Hijâz telah membangun aliansi yang bertujuan untuk mengamankan jalur perdagangan mereka. Makkah sebagai pusat, telah dianggap sakral, sehingga Hijâz secara ekonomi diuntungkan dengan keberadaannya. Mekah, secara politik tidak terpengaruh oleh konflik-konflik yang ada disekitarnya. Namun, sekitar tahun $570 \mathrm{M}$, tahun di mana Nabi Muhammad dilahirkan, tempat suci Mekah hampir hancur. Menurut sejarawan Muslim awal, insiden itu dipicu oleh pembangunan sebuah gereja yang megah di Sana'a, yang ditafsirkan oleh orang Mekah sebagai upaya untuk menyaingi Ka'bah dan mengalihkan ziarah Arab ke Abbasinia. Orang Arab kemudian beraksi atas bangunan tersebut, sehingga menjadikan Abrahah, sebagai pemimpinnya bertekad untuk membalas dan menghancurkan Ka'bah. Tentara Abraha bersiap untuk perang dan berbaris menuju Mekah dengan seekor gajah yang akan membantu mereka menghancurkan bangunan

${ }^{31}$ Ingrid Mattson, The Story of The Qura'an: Its History and Place in Muslim Life (West Sussex: Wiley-Blackwell, 2013), hal. 1.

32 Mattson, hal. 2.

33 Aĥmad MuŞțafâ Al-Marâghî, Tafsîr Al-Marâghî, vol. 30 (Mesir: MuŞţafâ al-Bâb al-Ĥalabî, 1946), hal. 243.

${ }^{34}$ Kathîr, Tafsîr Al-Qur'an Al-'Áìm, 1999, hal. 483.

${ }^{35}$ Wahbah Al-Zuhaylî, Al-Tafsîr Al-Munîr, vol. 30 (Damaskus: Dâr al-Fikr, 1418), hal. 408.

${ }^{36}$ Fakr al-Dîn Al-Râzî, Mafâtîh Al-Ghayb, vol. 32 (Bairut: Dâr al-Fikr, 1981), hal. 293. 
Ka'bah. Dalam penyebutan Mattson, ia mengutip pendapat sarjana muslim yang menjelaskan bahwa tentara bergajah tersebut dihancurkan oleh sekawanan burung yang memenuhi langit dan melempari batu. Kejadian ini menurut Mattson sebagai indikasi bahwa Tuhan melindungi dan memberkati Ka'bah. ${ }^{37}$

\section{DISKUSI}

\section{Rekonsiliasi Pemahaman: Memahami Tafsir secara Dialogis-Akomodatif}

Penafsiran yang dilakukan oleh sarjana Islam memiliki kecenderungan terhadap penafsiran yang didasarkan oleh pengalaman dan pengetahuan keberagamaannya. Dalam dua bentuk penafsiran yang disebutkan, ketika memahami mengenai ayat hukum, kecenderungan yang digunakan adalah berkaitan dengan hukum-hukum yang dikenal dalam kajian fikih. Begitu juga saat memberikan penjelasan terhadap peristiwa Abrahah ke Makkah yang hanya mengandalkan interpretasi ayat dalam wilayah kebahasaannya. Dimensi sosial historis dari ayat tersebut terlepaskan. Sedangkan sarjana Barat justru memberikan narasi konteks historis yang lebih mendalam. Akan tetapi, kajian hukum tidak dijelaskan secara spesifik. Ia hanya memberikan konteks tradisi Arab yang berkaitan dengan posisi perempuan. Hal yang sama juga dipahami dalam peristiwa penyerangan Abrahah ke Makkah.

Sudut pandang yang diberikan oleh para sarjana Islam membuktikan posisinya sebagai partisipan murni. Mereka merupakan para Ulama yang berupaya menjelaskan kandungan makna al-Qur'an sesuai dengan aturan-aturan ketat yang diyakini. ${ }^{38}$ Mereka memiliki kecenderungan untuk bertahan pada setiap aturan hukum yang terkandung dalam narasi ayat. Sedangkan makna yang dijelaskan oleh sarjanawan Barat lebih terfokus pada kondisi sejarah, kultur dan konteks masyarakat Arab disaat ayat diturunkan. Sarjanawan Barat melakukan pemaknaan terhadap ayat tanpa merasa terlibat atas konsekuensi hukum yang dihasilkan, sehingga mereka tidak memiliki tekanan secara psikologis maupun sosiologis. ${ }^{39}$ Meskipun demikian, Mattson tidak dapat lepas begitu saja terhadap konsep teologisnya sendiri. Ia masih tidak dapat memisahkan konsep "rasa bersalah" ketika seorang muslim melakukan perkara yang dilarang oleh Tuhannya. Hal ini nampak dari penjelasannya mengenai motif Hawlah untuk bertahan untuk tetap menjadi suami Aus. Padahal, dalam sisi hukum, rasa tidak ingin berdosa menjadi dorongan utama dalam mencegah atau melaksanakan suatu perintah. ${ }^{40} \mathrm{Hal}$ demikian, justru semakin menguatkan bahwa penafsiran yang dilakukan oleh komunitas muslim terhadap al-Qur'an maupun penafsiran yang dilakukan oleh peneliti di luar Islam terhadap al-Qur'an akan kesulitan untuk menjaga netralitas, imparsialitas, objektivitas, dan reduksionisme dari hasil penelitiannya. ${ }^{41}$

Upaya untuk mempertemukan kedua model penafsiran dapat dilakukan dengan mempertemukan keduanya ke dalam satu titik dengan menekankan dialektika singular. ${ }^{42}$

${ }^{37}$ Mattson, The Story of The Qura' an: Its History and Place in Muslim Life, hal. 7-8.

38 Knott, "Insider/Outsider Perspective," hal. 264.

${ }^{39}$ Knott, hal. 247.

${ }^{40}$ Muĥammad bin 'Alî Al-Shawkânî, Irshâd Al-Fuhûl (Beirut: Dâr al-Kutub al-'Ilmiyah, 1994), hal. 295.

41 Arvind Pal Sing Mandair, Thinking Differently about Religion and History (Curzon: Ritzmon, 2001), hal. $47-$ 48.

${ }^{42}$ Richard J. Barnstein, Beyond Objectivism and Relativism: Science, Hermeneutics and Praxis (Philadelphia: University of Pennsylvania, 1988), hal. 223-225. 
Penjelasan mengenai ziihar yang menjadi fokus penjelasan kalangan mufassir dapat dipertemukan dengan motif yang menjadi fokus utama kajian Mattson. Realitas hukum ìihar sebelum diturunkan Q.S. al-Mujâdalah (58): 1-2 berkaitan dengan aturan yang diyakini oleh orang Arab mengenai salah satu bentuk cara untuk mentalak istrinya. Konteks ini membuktikan bahwa realitas ayat, berkaitan penuh dengan realitas konteks pada masa turun. Hal demikian diperkuat oleh pandangan Naşr Hâmid Abû Zayd yang menyebutkan bahwa alQur'an adalah teks yang tidak terlepas dari konteks. ${ }^{43}$ Hal yang sama juga dijelaskan oleh Mattson dengan mengungkapkan motif Hawlah untuk tidak berpisah dengan suaminya, yakni berkaitan dengan upaya mempetahankan kehormatan yang dimilikinya yang didapatkan ketika ia mempunyai suami. Hal semacam ini menjadi hal yang lumrah dalam keadaan sosial Arab yang pathiraki. ${ }^{44}$ Terlebih, dalam penjelasan para mufassir, keengganan Hawlah berpisah dengan suaminya disebutkan alasan memikirkan kondisi suami dan anak-anaknya. Kedua pendapat tersebut pada dasarnya dapat disatukan dengan menyebutkan bahwa motif Hawlah datang kepada Rasul agar dia tidak berpisah dengan suaminya. Alasan Hawlah tidak ingin berpisah bisa jadi untuk mempertahankan kehormatan yang dimiliki, bisa jadi juga karena melihat keadaan suami dan anaknya.

Sedangkan dalam konteks pemahaman atas Q.S. al-Fîl, perbedaan keduanya terletak pada momen sejarah. Para mufassir klasik terfokus pada momen kejadian penyerangan Abrahah ke Makkah dalam konteks kelahiran Nabi Muhammad. Pengambilan momen ini menyebabkan masyarakat menjadi komunitas yang pasif dalam peristiwa ini. Satu-satunya kelompok yang agresif dalam konteks cerita yang dihadirkan oleh sarjana Islam adalah tentara Abrahah. Hal ini dapat diterima karena momen penyerangan tersebut bertujuan sebagai peristiwa awal yang mulya sebagai petanda lahirnya Nabi Muhammad. Hal yang berbeda dilakukan oleh Mattson yang momennya mengambil konteks sejarah Arab secara luas. Dengan adanya momen yang lebih luas yang berkaitan dengan aspek sosial, ekonomi dan budaya Arab, menjadikan Mattson memberikan narasi ancaman bagi masyarakat Arab terhadap adanya bangunan gereja yang di bangun di Abbasyania. Respon yang ditunjukkan oleh orang Arab terhadap bangunan tersebut, memunculkan respon balik Abrahah yang berujung pada penyerangan dan upaya menghancurkan Ka'bah. Meskipun demikian, Mattson menyepakati tanpa ragu atas keyakinan umat Islam mengenai kehancuran tentara Abrahah yang disebabkan oleh sekelompok burung yang melemparkan batu ke tentara tersebut hingga musnah. Terdapat kesamaan pemahaman diantara keduanya berkaitan dengan posisi Ka'bah yang dapat dijadikan benang merah untuk mempertemukan kedua pandangan ini. Mattson menyebutkan bahwa Ka'bah memberikan keunggulan khusus kepada orang Arab dalam menghidupkan perekonomiannya. Hal yang sama juga disebutkan dalam tafsir klasik yang menyatakan Ka'bah sebagai bangunan suci. Pembangunan gereja yang megah oleh Abrahah bisa jadi didorong oleh motif yang sama untuk memancing para peziarah untuk datang ke wilayahnya. Hal tersebut berpengaruh pada aspek ekonomi dan politik bagi Abrahah. Respon orang Arab terhadap bangunan Abrahah, hanyalah percikan kecil yang semakin mengobarkan keinginan Abrahah untuk mencapai tujuannya, sehingga mendorong Abrahah untuk menghancurkan Ka'bah agar para peziarah yang datang ke Makkah beralih ke Abbasyania.

43 Zayd, Tekstualitas Al-Qur'an: Kritik Terhadap Ulumul Qur'an, hal. 30.

${ }^{44}$ Issa J. Boulatta, Dekonstruksi Tradisi: Gelegar Pemikiran Arab Islam, trans. Imam Khoiri (Yogyakarta: LKiS, 2001), hal. 122. 
Upaya untuk melibatkan penafsiran sarjana Barat dalam pemahaman al-Qur'an yang telah diberikan oleh para mufassir untuk menghindarkan diri dari klaim kebenaran atas makna suatu ayat. Dengan mendatangkan perspektif lain di luar pemahaman kalangan Islam sendiri dalam memahami ayat, berarti pemahaman atas ayat tersebut dihasilkan dari proses elaborasi metode kritis objektif sarjana Barat dalam memandang al-Qur'an. ${ }^{45}$ Sintesis dalam pemahaman antara insider dan outsider dalam kerangka penafsiran yang sifatnya reflektif-sirkuler memungkinkan memperoleh pemahaman yang objektif yang banyak di usahakan oleh sarjana muslim kontemporer. Kajian ini juga dapat menjadi kajian alternatif selain metode hermeneutika untuk menemukan objektivitas dalam penafsiran.

Kajian ini pada dasarnya berpotensi untuk memberikan kontribusi dalam pengembangan metode penafsiran yang berkaitan dengan problem objektivitas dan subjektivitas. Meskipun demikian, upaya untuk meletakkan dua pandangan yang memiliki kecenderungan subjektivitas masing-masing masih diperlukan pengujian yang lebih intens lagi. Hal ini berkaitan dengan posisi sarjana Barat sebagai peneliti mutlak yang meletakkan alQur'an sebagai objek penelitian murni. Sedangkan kalangan Islam, memiliki kecenderungan teologis yang membatasi setiap upaya penafsiran di luar teks-teks keagamaan. Oleh sebab itu, penelitian yang berkaitan dengan pendekatan inter-subjektif yang dapat meletakkan kedua kecenderungan tersebut dalam posisi yang singular perlu dilakukan pendalaman.

\section{KESIMPULAN}

Anggapan banyak kalangan mengenai ketidakabsahan melakukan pembacaan terhadap produk tafsir sarjana Barat, tidak cukup berasalan. Hasil penafsiran tersebut justru berkontribusi dalam usaha untuk meminimalisir kecenderungan aliran yang banyak terdapat dalam tafsir klasik Islam. Penelitian ini menunjukkan bahwa pembacaan Barat yang tidak memiliki tendensi aliran apapun mampu memberikan pandangan lain dalam memahami al-Qur'an. Penelitian ini menunjukkan bahwa ayat mengenai zijhar yang cenderung dipahami dalam konteks hukumnya, ternyata memiliki kaitan erat dengan motif-motif sosial-historis masyarakat Arab pada masa ayat turun. Motif ini dapat dilihat dari upaya Khawlah yang dimaksudkan dalam ayat tersebut, dalam hal mempertahankan suaminya. Pemahaman melalui konteks ini, pada dasarnya tidak mengubah konsekuensi hukumnya. Hal yang sama juga dibuktikan dengan penjelasan motif penyerangan Abrahah yang dipengaruhi oleh keberadaan Ka'bah yang dimiliki oleh suku Qurash. Pemahaman semacam ini dihasilakan dari upaya sintesis atas pemahaman sarjana Barat dengan pemahaman para mufassir klasik.

Upaya melakukan sintesis atas dua pandangan ini dicapai dengan perspektif insideroutsider yang dikenalkan oleh Kim Knott. Metode ini berhasil mensintesiskan pemahaman peneliti murni (Barat) dengan partisipan murni (Islam) dalam satu tapal batas dengan mencari titik temu dari kedua pandangan. Pertemuan ini mensyaratkan hubungan reflektif-singular yang saling mengisi, sehingga antara pandangan yang satu dengan pandangan yang lainnya tidak saling mentiadakan.

45 Muhammad Abdul Rauf, "Outsider's Interpretation of Islam," in Approaches to Islam in Religious Studies (Oxford: Oneworld Publication, 2001), hal. 185. 
Meskipun demikian, penelitian ini hanya memberikan pandangan dalam kasus-kasus tertentu dengan melibatkan tokoh-tokoh tertentu. Untuk menghasilkan pembuktian yang lebih meyakinkan, maka diperlukan kajian lain yang lebih mendalam dengan melibatkan banyak tokoh agar terdapat variasi dalam proses pemahamannya.

\section{REFERENSI}

Abduh, Muhammad. Tafsîr Al-Qur'an Al-Karîm Juz 'Amma. Kairo: Mața’ah Mişr, 1341.

Adams, Charles J. "Islamic Religious Tradistion." In The Study of the Middle East: Research and Scholarship in the Humanities and the Social Sciences, edited by Leonard Binder. New York: Wiley, 1976.

Ahmadi. "Perspektif Insider/Outsider Dalam Studi Agama (Mengurai Gagasan Kim Knott)." Jurnal Al-Himayah 2, no. 2 (October 1, 2018): 191-204. http://journal.iaingorontalo.ac.id/index.php/ah.

Al-Marâghî, Aĥmad Muşţafâ. Tafsîr Al-Marâghî. Mesir: Muşţafâ al-Bâb al-Ĥalabî, 1946.

Al-Qațțân, Mannâ' Khalîl. Mabâhith Fî̀ Ulùm Al-Qur'an. Riyâđ: Manshûrât al-'Aşr al-Ĥadîth, 1973.

Al-Râzî, Fakr al-Dîn. Mafâtîh Al-Ghayb. Bairut: Dâr al-Fikr, 1981.

Al-Shawkânî, Muhammad bin 'Alî. Irshâd Al-Fubûl. Beirut: Dâr al-Kutub al-'Ilmiyah, 1994.

Al-T,abarî, Muhammad bin Jarîr. Jâmi' Al-Bayân Fî̀ Ta'mîl Al-Qur'an. Beirut: Muassasah alRisâlah, 2000.

Al-Zuhaylî, Wahbah. Al-Tafsîr Al-Munîr. Damaskus: Dâr al-Fikr, 1418.

Arkoun, Mohammed. "Contemporary Critical Practices and The Quran.” In Encyclopedia of The Quran, edited by Jane Dammen McAuliffe, Leiden: Brill, 2001.

—. "Towards a Radical Thinking of Islamic Thought." In Modern Muslim Intellectual and The Quran, edited by Suha Taji-Faruki. Oxford: Oxford University Press, 2004.

Barnstein, Richard J. Beyond Objectivism and Relativism: Science, Hermeneutics and Praxis. Philadelphia: University of Pennsylvania, 1988.

Boulatta, Issa J. Dekonstruksi Tradisi: Gelegar Pemikiran Arab Islam. Translated by Imam Khoiri. Yogyakarta: LKiS, 2001.

Fermadi, Bayu. "Insider-Outsider Dalam Studi Islam.” Jurnal Ilmiah Spiritualis: Jurnal Pemikiran Islam Dan Tasawuf. Vol. 4, 2018. http://ejurnal.iaipdnganjuk.ac.id/index.php/spiritualis/article/view/49.

Hanafî, Hasan. Al-Turâth Wa Al-Tajdìd: Mawqifuna Min Al-Turâth Al-Qadîm. Beirut: Muassasah al-Jamiiyah, 1992.

Hanafi, Hasan. "Method of Thematic Interpretation of The Quran." In The Quran as Text, edited by Stefan Wild. Leiden: E.J. Brill, 1996.

Hery, Musnur. "Pengembangan Studi Islam Perspektif Insider-Outsider." Intizar 22, no. 2 
(December 24, 2016): 199. https://doi.org/10.19109/intizar.v22i2.941.

Kathîr, Ismâil bin Umar bin. Tafsîr Al-Qur'an Al-'Ażim. Riyâđ: Dâr al-T,ayyibah, 1999.

Khoiruddin, Untung. "Insider/Outsider Perspective in Religions and Islamic Studies." Jurnal Pemikiran Keislaman 24, no. 2 (September 23, 2015). https://doi.org/10.33367/tribakti.v24i2.175.

Knott, Kim. "Insider/Outsider Perspective." In The Routledge Companion to The Study of Religion, edited by John R. Hinnells. New York: Routledge, 2005.

Mahr, Husayn Alawî. Al-Madhkhal Ila Târikh Tafsîr Wa Al-Mufassirîn. Iran: Markaz Musţafâ al'Alamî, 1392.

Mandair, Arvind Pal Sing. Thinking Differently about Religion and History. Curzon: Ritzmon, 2001.

Mattson, Ingrid. The Story of The Qura'an: Its History and Place in Muslim Life. West Sussex: WileyBlackwell, 2013.

Miles, Matthew B., and A. Michael Huberman. Qualitative Data Analysis (a Source Book of New Methods). Beverly Hills: SAGE Publications, 1984.

Mustaqim, Abdul. Epistimologi Tafsir Kontemporer. Yogyakarta: LKiS, 2011.

Patton, Michael Quinn. How to Use Qualitative Methods in Evaluation. New York: SAGE Publications, 1987.

Rahman, Fazlur. Islam Dan Modernitas Tentang Tranformasi Intelektual. Translated by Ahsin Mohammad. Bandung: Penerbit Pustaka, 1985.

- "Some Recent Books on the Qur'ān by Western Authors." The Journal of Religion 64, no. 1 (January 22, 1984): 73-95. https://doi.org/10.1086/487077.

—. Tema-Tema Pokok Al-Qur'an. Translated by Anas Mahyuddin. Bandung: Pustaka, 1980.

Rauf, Muhammad Abdul. "Outsider's Interpretation of Islam." In Approaches to Islam in Religious Studies. Oxford: Oneworld Publication, 2001.

Rippin, Andrew. “Analisis Sastra Terhadap Al-Qur'an, Tafsir Dan Sirah: Metodologi John Wansbrough.” In Pendekatan Kajian Islam Dalam Studi Agama, edited by Richard Martin, translated by Zakiyuddin Baidhawy. Surakarta: Muhammadiyah University Press, 2001.

"Foreword." In Quranic Studies: Sources and Methods of Scriptural Interpretation, translated by Andrew Rippin. New York: Prometheus Books, 2004.

Shihab, M.Quraish. Kaidah Tafsir Syarat, Ketentuan, Dan Aturan Yang Patut Anda Ketahui Dalam Memahami Ayat-Ayat Al-Qur'an. Tangerang: Lentera Hati, 2013.

Suarni, Suarni. "Pendidikan Islam Menjawab Tantangan Suarni." Tarbany: Jurnal Pendidikan Islam. Vol. $\quad 6, \quad$ December 2019. https://jurnal.lp2msasbabel.ac.id/index.php/tar/article/view/1237.

Zakariya, Zakariya Hâkim. Al-Mushtashriqûn Wa Al-Islâm. Kairo: Dâr al-Kutb al-'Arabiyah, 1965.

Zayd, Nasr Hamid Abu. Al-Qur'an, Hermeneutika, Dan Kekuasaan. Translated by Dede Iswadi, 
A. Rohman, and Ali Mursyid. Bandung: Reseach for Quranic Studies, 2003.

- Telestualitas Al-Qur'an: Kritik Terhadap Ulumul Qur'an. Translated by Khoiron Nahdliyyin. Yogyakarta: LKiS, 2013. 